\title{
CLERGY'S RESISTANCE TO VENDA HOMELAND'S INDEPENDENCE IN THE 1970S AND 1980S
}

\author{
S.T. Kgatla \\ Research Institute for Theology and Religion \\ University of South Africa \\ kgatla@mweb.co.za
}

\section{ABSTRACT}

The article discusses the clergy's role in the struggle against Venda's "independence" in the 1970s and 1980s, as well as resistance to the apartheid policy of "separate development" for Venda. It also explores the policy of indirect white rule through the replacement of real community leaders with incompetent, easily manipulated traditional chiefs. The imposition of the system triggered resistance among the youth and the churches, which led to bloody reprisals by the authorities. Countless were detained under apartheid laws permitting detention without trial for 90 days. Many died in detention, but those responsible were acquitted by the courts of law in the Homeland. The article highlights the contributions of the Black Consciousness Movement, the Black People Conversion Movement, and the Student Christian Movement. The Venda student uprising was second in magnitude only to the Soweto uprising of 16 June 1976. The torture of ministers in detention and the response by church leaders locally and internationally, are discussed. The authorities attempted to divide the Lutheran Church and nationalise the Lutherans in Venda, but this move was thwarted. Venda was officially re-incorporated into South Africa on 27 April 1994.

Keywords: Independence; resistance; churches; struggle; Venda Homeland

\section{UNISA $\cong$}




\section{INTRODUCTION}

The logical conclusion of the apartheid policy of separate development in South Africa was the establishment of Homelands ${ }^{1}$ to which black people could be relegated for the convenience of white people. ${ }^{2}$ Black people were either persuaded to leave their land peacefully ${ }^{3}$ or were forcefully removed to these Bantustans. After the formation of the Union of South Africa in $1910,{ }^{4}$ but especially after 1948, when the Nationalist Party came to power, successive prime ministers and their ministers of native or Bantu affairs worked towards the implementation of a policy of separate development. Speaking in the Senate Chamber in 1954, H.F. Verwoerd ${ }^{5}$ proclaimed the objective of the Nationalist Party to be the control of "native education" and its reform such that black people would be taught from childhood to realise that equality with whites was not a prospect for them. ${ }^{6}$ Nico Smith also affirms this in his book Tshilidzini: Christian Missionary Work in an Apartheid Context. The government

1 While "homeland" is usually not capitalised in studies of these areas, this paper will use capital letters to stress the misleading nature of the term, which was part of the apartheid vocabulary and propaganda.

2 There was resistance to the granting of independence to other Homelands, but not to the same extent as with Venda. Similar to the other Homelands, Venda's independence was a farce according to Bishop N.P. Phaswana, of the Evangelical Lutheran Church in Southern Africa, Central Diocese (Phaswana: Interview, 16 November 2013). The population was very low - only about 350000 people (Rand Daily Mail, 19 January 1982). Literacy was low and the region was very traditional. The region designated as the Venda Homeland had no natural resources to feed its people, so opting for independence was suicidal. Chief Mphephu, the first Homeland president, was not sufficiently educated to understand the situation. There was overwhelming support for the opposition party, which both the Venda Traditional Authority and the South African government tried to suppress. The events of the youth riot of June 1976 exacerbated the issues. Venda is close to the northern border of South Africa, where freedom fighters could easily gain entry.

3 In June 1983, the then deputy minister of development and land affairs, Hennie van der Walt, said: "I readily admit that we made mistakes in the past. So much so that black communities had to be removed by force and often resettled in critical circumstances. Our biggest mistake was that we did not undertake these resettlement actions in co-operation with the black communities. A lack of consultation between the government and the black people concerned led to numerous unfortunate incidents... The days when police had to help load people onto trucks and the resistance which followed certain actions amongst black people are past" (cited by Aninka Claassens: "The Myth of Voluntary Removals," in The Black Sash, May 1994, 20-30, URL http://www.historicalpapers. wits.ac.za/inventories/inv_pdfo/AK2117/AK2117-J7-DA151-002-jpeg.pdf (accessed 26 December 2013).

4 The Native Affairs Act of 1920 provided for the establishment of local councils and a Native Commission to advise the government on issues affecting black people.

5 Then minister of native affairs, and in charge of Bantu Education, later prime minister of South Africa.

6 Nico J. Smith: Elkeen in sy Eie Taal, N.G. Kerk Boekhandel, Pretoria 1972, 68. Smith analyses the Dutch Reformed Church mission policy in his book. 
used various methods to achieve the desired goals and objectives of this policy, ${ }^{7}$ including the control of all laws passed by Homeland leaders.

The final step in implementing the policy was the National States Citizenship Act of 1970. This act permitted black people citizenship only in Homelands. ${ }^{8}$ In terms of the policy, black South Africans were to become citizens of 10 Homelands according to their ethnic grouping under the Republic of South Africa's SelfGoverning Territories Constitution Act of 1971, depriving them of their birth-right citizenship as South Africans. In terms of this legislation, many black people were either forcefully or indirectly removed from the patches of land that were declared white areas into the areas designated for the Homelands. To this end, the Republic of South Africa issued Proclamation R. 168 of 20 June 1969 to create the Venda Territorial Authority (to replace the Thohoyandou Territorial Authority), which was to be responsible for the designated area situated within the then Northern Transvaal region. The move met with stiff resistance from local people. ${ }^{9}$

\section{METHODOLOGY}

The methodology followed in the study underlying this article, is a qualitative approach of field work, based on the interview of church clergy who were directly involved in the struggle against Venda independence. Most of the ministers who participated in the interview exercise were from Evangelical Lutheran Church in Southern Africa (ELCSA). According to Dean Farisani (Interview, 9 December 2013), at the time of the struggle against the Venda independence the ELCSA formed 50 per cent of Christian Churches in Venda.

The policy of separate development generated strong opposition from black people, resulting in the brutal and violent loss of many lives. ${ }^{10}$ This paper investigates the struggle of members of the black clergy against the formation of one of the smallest Homelands, namely Venda, which was granted independence on 13 September 1979. Venda ${ }^{11}$ was one of four Homelands granted independence - the Transkei, Bophuthatswana, Venda and the Ciskei (known as the TBVC states). The other six

7 The goal envisaged in the government's policy of separate development was to create a South Africa populated only by whites, with black populations quarantined to reserves for proper internal and external security control and for exploitation as cheap labour; Dean T.S. Farisani, ELCSA: Interview, 9 December 2013; Bishop N.P. Phaswana, ELCSA, Central Diocese: Interview, 16 November 2013.

8 Republic of South Africa. The Act was originally called the Bantu Homelands Citizenship Act, No. 26 of 1970. The act infamously refers to black people as "excess people".

9 Republic of South Africa, Proclamation R. 168, 20 June 1969.

10 The Sharpeville massacre and a plethora of other atrocities became part of South African history.

1112 Venda was a Homeland for the Tshivenda-speaking people. The Homeland was situated in the north-eastern part of South Africa, close to the Zimbabwean border. In 1973, the Homeland had an estimated population of 223000 , and the population was estimated at 600000 in 1996. It occupied an area of about $6807 \mathrm{~km} 2$. 
designated areas were granted self-governing status, but not full independence. This chapter investigates the role of the clergy from three denominations (the ELCSA, the Dutch Reformed Church in Southern Africa, and the Reformed Church) that operated in Venda during Venda's independence. This role is investigated using a variety of published and unpublished sources, and drawing on eyewitness accounts provided in interviews in November and December 2013 with five people who were active in and/or witnessed that struggle. These accounts were provided by Bishop N.P. Phaswana (Interview, 16 November 2013), Dean Uriah Seakamela (Interview, 28 November 2013), Dr H. Ramantswana (Interview, 3 December 2013), Dean T.S. Farisani (Interview, 9 December 2013), and Mr Justice Thovhogi (Interview, 13 December 2013). ${ }^{12}$

The architects of apartheid knew that most black people in South Africa would not accept the system for obvious and practical reasons. To avoid opposition, the government employed less-educated chiefs to implement the system. ${ }^{13}$ People knew that the "independent Homelands" were a farce and served white greed, self-preservation, and labour reservation. It denied black people their birth-right citizenship and their inheritance from their forefathers. The majority of black people in South Africa wanted to remain citizens of South Africa, but several of their traditional leaders, who could be bribed and could not recognise the consequences of the policy, opted for independence. For many, relinquishing South African citizenship and taking up an allocated place under corrupt traditional chiefs and leaders in barren land was unimaginable, but the rulers would not relent, even in the face of fierce hostility by their own people. ${ }^{14}$

\section{REFORMED AND LUTHERAN MISSIONARIES ARRIVE IN VENDALAND}

The Voortrekkers established themselves at the foot of the Soutpansberg between 1836 and 1837. Successive waves of missionaries followed. ${ }^{15}$ The missionaries from the Dutch Reformed Church were the first to arrive in 1863, under the leadership of Alexander McKidd, who spent only two years in the area before he died of malaria

12 Bishop Phaswana is currently serving as Presiding Bishop of the Evangelical Lutheran Church of Southern Africa (ELCSA). Dean Seakamela and Dean Farisani are both retired deans of the ELCSA. Dr Ramantswana is a senior lecturer at the University of South Africa and a minister of the Reformed Church Soutpansberg Synod, while Mr Thovhogi is an elder in the Uniting Reformed Church in Southern Africa (URCSA).

13 Phaswana: Interview, 16 November 2013.

14 In my interviews with them, Phaswana and Farisani gave the following reasons for the Venda people's rejection of independence: Venda leaders were greedy and only looked after their own interests; they realised that they could never ascend to any leadership position if the whole of South Africa was freed; they were misled into accepting the independence and they loved power.

15 Alan Kirkaldy: Capturing the Soul. The Vhavenda and Missionaries, Pretoria 2005, 20. 
in 1865 . He was succeeded by Stephanus Hofmeyr who settled mainly among the Sotho-speaking people. ${ }^{16}$ The second group of missionaries to arrive in Venda were Lutherans sent by the Berlin Missionary Society. They established themselves first in Sekhukhuneland in the south and Blaauberg in the west. Then they came to Vendalocated east of the Soutpansberg - in 1872, after the Lutheran missionaries Grutzner, Beyers, Beuster, and Stech visited Tshivhase, the Vhavenda paramount chief, to request his permission to start mission work in his territory. ${ }^{17}$ The mission station in the territory of Chief Tshivhase was followed by two other mission stations: the station at Tshakhuma in the territory of Chief Madzivhandila in 1874, and the station in the territory of Chief Makwarela Mphaphuli in 1877. The Reformed Church was the third church to gain a foothold in Venda, in 1928, in the territory of Chief Nzhelele. $^{18}$

The success of missionaries in Vendaland was largely due to a number of previously converted local Christians whose presence in the area was of great help to the missionaries. These "already Christians" continued to play a crucial role in the spread of the gospel among their own people. Since the missionaries lacked the necessary linguistic, political and social skills to engage with the chiefs and their followers on all levels, these "already Christians" and "unsung heroes" did almost everything for the missionaries. ${ }^{19}$ The "already Christians" had received the gospel as migrant workers in the Cape, in Port Elizabeth and in Kimberly. Now they became evangelists and took care of the mission stations and remote outposts. Some had come into contact with missionaries from the Parys Missionary Society and, subsequently, underwent training as evangelists in Lesotho. They were readily available for missionary work in Venda, serving as guides and interpreters for missionaries, not to mention as advisers on African cultural protocol. Kirkaldy ${ }^{20}$ mentions eight such "previously converted Christians" in Venda at the time of the arrival of the Berlin Missionaries; furthermore, Crafford ${ }^{21}$ claims that, around 1887, there were 21 of them in the Dutch Reformed Church, mainly among the Sotho people in the south. When the Dutch Reformed Church missionary A.A. Louw volunteered to cross the Limpopo River to start mission work in Mashonaland, he took seven of these "pioneers" with him and deployed them at various mission stations from the Bubi river in the south to as far north as Morgenster in the middle of what is now Zimbabwe. ${ }^{22}$

16 D. Crafford: Aan God die Dank, N.G. Kerk Boekhandel, Pretoria 1982, 63.

17 Kirkaldy, Capturing, 27.

18 Crafford, Aan God die Dank, 341.

19 S.T. Kgatla: Polokwane Congregation: Uniting Reformed Church in Southern Africa: An Historical Survey since 1890, Polokwane 2013, 14; Kirkaldy, Capturing, 52-53.

20 Kirkaldy, Capturing, 53.

21 Crafford: "God," in Trial-blazers of the Gospel, 1991, 80-90.

22 Kgatla, Polokwane, 18. 
According to statistics gathered by Kritzinger, the three churches had about 25000 members in Venda in 1981. Of the three, the Lutheran Church was the largest at 15000 members, followed by the Dutch Reformed Church with about 5 770, and the Reformed Church with about $4830 .{ }^{23}$ The fact that the Lutheran Church had three times as many members as the Dutch Reformed Church may be ascribed to two factors. First, the Lutheran missionaries had approached the major Venda chiefs for permission to start missionary work among their people and had worked closely with the chiefs. By contrast, the Dutch Reformed Church missionaries had approached settlers, such as Lottering at Kranspoort and the leaders of the Afrikaner Republics, for land to start mission work. Second, the relationships between the Lutheran missionaries and the local people were more open and trustful than those of the Dutch Reformed Church with the local people. Because the allegiance of the Dutch Reformed Church missionaries lay with their counterparts in the white government(s), they were sympathetic to white people's interests rather than those of their black converts. ${ }^{24}$

\section{STRATEGY FOLLOWS STRUCTURE - EN ROUTE TO INDEPENDENCE}

The possibility arose of Venda's independence when the Bantu Authorities Act of $1951^{25}$ was promulgated to create tribal, regional and territorial authorities. In the case of Venda, three regional authorities and one territorial authority were established. Venda people were recognised as distinct from other ethnic groups, as a homogeneous entity in need of their own homeland. In 1962, the Thohoyandou Territorial Authority was established, headed by Chief Patrick Mphephu; 25 tribal authorities were represented in the regional authority by chiefs. ${ }^{26}$

Proclamation R.168 of 20 June 1969 declared the Thohoyandou Territorial Authority to be the official Venda Homeland Territorial Authority, pushing the region further towards independence as a Homeland; the Homeland was then made official in 1979. The Proclamation brought about many changes that led to almost every tribal structure being represented by the chiefs or traditional leaders. Next, the Black States Constitution Act of $1971^{27}$ provided for the creation of legislative assemblies in the Homelands. The Venda Legislative Assembly was then constituted in terms of this Act in 1973, and Venda became a self-governing territory that year. Venda

23 Crafford, God, 342.

24 S.T. Kgatla: The Dutch Reformed Church Mission Since 1863-1964. Unpublished MTh. Dissertation, UNISA, 1988, 56.

25 Union of South Africa, 1951.

26 D. Geldenhuys: South Africa's Black Homelands. Past Objectives, Present Realities and Future Developments. The South African Institute of International Affairs. Braamfontain. 1981.

27 Also known as the Bantu Homelands/Black Homelands/Self-Governing Territories Constitution Act. 
eventually became an independent state in 1979 and was known as the Republic of Venda, with Chief Patrick Mphephu as the first president. ${ }^{28}$ The "independence" of the homeland states was a manifestation of the success of the national government in Pretoria in imposing tribal divisions, but it sowed seeds of hatred, hostility, violence, and stout resistance towards those who became rulers in the independent states. ${ }^{29}$

Behind the scenes, the South African government wanted to use indirect rule to make Africans proud of their culture - so they would not want to be like white people or live among them - without embracing the philosophy of the Black Consciousness Movement. ${ }^{30}$ The methodological considerations employed to implement the system involved identification of the local power structures and the invitation and/or bribery of chiefs to become implementers of the system. In order to make the policy work, the chiefs were given protection, a salary, a bakkie, ${ }^{31}$ a house and gifts to distance them from their people and encourage them to listen to their white masters. ${ }^{32}$

The colonial view of an African chief as an important link between his people and the white government was effectively applied in Venda. ${ }^{33}$ Interactions between various stakeholders within the community were severely restricted and discouraged, allowing the authorities to sow division within communities and play one group against the other. The South African government feared that national interaction might lead to activities that could support nationwide resistance to its policies. ${ }^{34}$ A "divide and rule" strategy was applied..$^{35}$ No dissent was tolerated. According to the Sowetan, a Johannesburg newspaper, Venda's rulers, like those of the other independent Homelands, came to power with the aid of South Africa and

28 Chief Mphephu formed his political party, the Venda National Party, only after his "election" in 1973 (Phaswana: Interview, 16 November 2013).

29 The Homeland independence policy would not be stopped once the intention was known. Brutal acts were committed to eliminate any opposition (Thovhogi: Interview, 13 December 2013).

30 The South African government considered Black Consciousness to be communist and misguided, because it threatened the philosophy of separate development (Phaswana: Interview, 16 November 2013).

31 The common South African term for a pick-up truck.

32 After the 1973 Venda election, Chief Minister Mphephu took 42 chiefs from the Venda Legislative Assembly to the Manyeleti Game Reserve, entertained them and bought them suits (Rand Daily Mail: 5 January 1982; Farisani: Interview, 9 December 2013).

33 The chiefs were not necessarily educated people and could not reason with the colonial rulers, but were made entirely dependent on the central government, including for their security.

34 Despite the enforcement of apartheid policies by harshness and force, the rural people of South Africa never relented in their resistance. Albert Luthuli summed it up in 1962 as the African voice: "we do not consent" to apartheid laws (cited in B. Turok: Readings in the ANC Tradition. Volume 1 Policy and Praxis, Cape Town 2011, 42.). Between 1946 and 1962 rural resistance was provoked in Witsieshoek, (Free State), Marico and Sekhukhuneland (former Transvaal), Zululand (Natal), the Transkei (Eastern Cape) and many parts of rural South Africa. Govan Mbeki: The Peasants' Revolt. Johannesburg 1964, 30.

35 Farisani: Interview, 9 December 2013. 
by detaining and harassing the opposition. ${ }^{36}$ The South African government found it easier to deal with unscrupulous chiefs (without formal schooling) whom it could easily manipulate, because it had more control over them than over the honest men of integrity who were imprisoned at Robben Island. ${ }^{37}$

Chief Patrick Mphephu became Venda's first president, even though he lost twice at the polls (in 1973 and $1978^{38}$ ) and lacked any solid education or administrative experience. He wielded power ruthlessly against his opponents in order to remain in the position to which he had been raised by the South African government. Dr J.S. Otto, the commissioner-general for Venda and the South African envoy in Venda, said on the occasion of Venda's independence that representatives of members of the Venda people had committed themselves to the democratic principles embodied in the Venda constitution. He added:

...you in Venda are setting an example to many states in this connection, where the democratic process has been swept away by the dictatorship and other systems which make a mockery of democracy. ${ }^{39}$

These words of praise by Dr Otto contradicted the words of his predecessor, De Wet Nel, who expressed frustration at the lack of understanding of parliamentary procedures among members of the Venda Legislative Assembly. He indicated that lectures would be arranged for them during the adjournment. ${ }^{40}$ Despite his repeated defeats at the polls by the more educated Baldwin Mudau, the former teacher and social worker Chief Patrick Mphephu became president, and not through a popular vote, but a traditional chiefs' vote. When Venda became independent, about 50 of the Venda Independent Party (VIP) supporters were arrested, including 13 of the members of Parliament from Mudau's party. ${ }^{41}$

Chief Patrick Mphephu had little education - he had only obtained Standard 6 (Grade 8) at the Tshakuma Lutheran Mission School, and could barely read or write in English or Afrikaans. ${ }^{42} \mathrm{He}$ was pushed into prominence largely under the wing of Venda Commissioner-General De Wet Nel. ${ }^{43}$ Initially, Chief Mphephu had been a Lutheran parishioner, but he left the Lutheran Church and became a Zionist because of the question of polygamy. Once in power, he dealt ruthlessly with political opponents, ${ }^{44}$ especially with outspoken Lutheran ministers. He brooked no opposition to his political agenda.

36 Sowetan: 2 February 1982.

37 Ibid.

38 Post Focus: 22 January 1982.

39 Cited in Uhuru, n.d. (unpublished paper).

40 Ibid.

41 Sowetan: 4 January 1982.

42 Sunday Express: 17 January 1982.

43 Ibid.

44 Phaswana: Interview, 16 November 2013. 
It is not difficult to imagine why black ministers and "transformed missionaries" were subjected to harsh reprisals in Venda. ${ }^{45}$ The activities of any members of the clergy who would not subscribe to white and state ${ }^{46}$ theology, who were poised to improve the awareness among blacks of the harsh realities of the apartheid system that was domesticating them, were severely curtailed. Some white (German) missionaries who showed sympathy towards black people and acted on their behalf were either arrested or deported. Some, like Christian Fobbe, were deported because of their sympathetic attitude towards black people. Hans Häselbarth, Richard Schele and Helmut Garthe were other German missionaries who had a difficult time with the apartheid government. ${ }^{47}$ Dr Wolfram Kistner, a white Lutheran minister who was vocal in denouncing apartheid, was also detained. ${ }^{48}$ In 1980, when many chiefs crossed the floor and it became clear that Chief Patrick Mphephu was going to be ousted, the chief closed the session in order to regroup. Subsequently, in 1981, many chiefs were taken to the Manyeleti Game Reserve, where they were persuaded with gifts and other bribes to elect him chief minister. ${ }^{49}$

\section{DEFINING MOMENTS OF THE RADICALISATION OF THE CLERGY AGAINST HOMELAND INDEPENDENCE POLICIES}

The radicalisation of clerics who openly opposed Venda's independence did not start in the institutional church, although some missionaries played a pivotal role in shaping their political awareness, such as Ms Hanna Schultze, who was one of the first outspoken critics of the apartheid system. Among the black activists were Joseph Mudluli, who was detained for political reasons and died in police detention in 1976; $;^{50}$ Tshifirwa Isaac Muofhe, a student of the Lutheran seminary in Venda, who died in police detention in November $1981{ }^{51}$ and clergymen Rev. T.S. Farisani, Rev. A.N. Mahamba, Rev. N. Phaswana, and Rev. P.M. Phosiwa, who became aware of the inhumane system of apartheid at an early age.

Dean T.S. Farisani had already experienced the realities of apartheid atrocities at the age of 12 , when his parents were twice forcibly removed from fertile land to

45 Seakamela: Interview, 28 November 2013.

46 Rev. Wesley Mabuza called this kind of theology a very superficial critique of apartheid, as well as an analysis of the prevailing context that lacks any depth but stresses the need for reconciliation and peace at the expense of justice. W. Mabuza: TRC presentation in November 1997.

47 Seakamela: Interview, 28 November 2013.

48 N. Phaswana: "Global Lutheranism. A Lutheran Memoir," Lutheran Forum 47, no. 3: 42-48.

49 Sunday Express: 17 January 1982.

50 Cape Times: 11 January 1981.

51 Cape Times: 22 January 1982. 
arid land. When the notorious act of culling black people's stock ${ }^{52}$ reduced Farisani's family to five head of cattle, he was devastated. These actions left his family in abject poverty and denied him any means of education. ${ }^{53} \mathrm{He}$ was subjected to humiliation and brutality by white farmers when he went to look for work to augment his parents' earnings and to save for his school fees. The false piety of white ministers, who were no different from the government when it came to the inhumane treatment of black people, convinced him of the shallowness of their religion, which had no dimension of socio-political justice and could be used as a tool in disguising apartheid. Thus apartheid was a reality to him even in his youth, before he became aware of the broad mass protest of the African Congress of the 1950s and 1960s.

Most of the ministers who were directly involved in opposing Venda's independence were from the Lutheran Church. Not all ministers in the Lutheran Church in Venda engaged in the struggle, but there were four prominent ministers who did join such endeavours. ${ }^{54}$ In answer to a question as to whether the whole church was involved in the struggle against Venda's independence, Bishop Phaswana said that this was not the case. He believes that the reason for cautious involvement in activism against Venda's independence by the institutional church was that the institutional church had never been prophetic, although some individuals within it were, and some that could become prophetic. ${ }^{55}$ Ministers from the Lutheran Church, whose church membership accounted for about 60 per cent of Christians in Venda at the time of independence, were placed in police detention because in their sermons they consistently took a strong line against Venda's independence. ${ }^{56}$ According to Phaswana, they knew that they would be persecuted for telling the truth, but they made the decision to be on the side of the truth, regardless of the hardship that would follow. ${ }^{57}$ The Reformed Churches and their ministers were hardly involved in the struggle. This was largely because the number of white missionaries who supported a policy of separateness exceeded the number of black ministers and students at seminaries..$^{58}$ Most of the black ministers in the Dutch Reformed Church had been trained at the Dutch Reformed Church seminaries that had been created in the late 1950s together with black universities, e.g., the Universities of the North, Zululand and Western Cape under the terms of the Extension of University Education Act of

52 In 1943, the Smuts government set up a scheme of rehabilitating reserves by culling stock to the carrying capacity of the communal pasturage. G. Mbeki: African National Congress Book, ANC, Johannesburg 1964, 64.

53 Farisani: Interview, 9 December 2013.

54 Cape Times: 10 February 1982.

55 Phaswana: Interview, 16 November 2013.

56 Sunday Express: 10 October 1982.

57 Phaswana: Interview, 16 November 2013.

58 Ramantswana: Interview, 3 December 2013. 
1959. ${ }^{59}$ The only exception was the ordained white minister of the Dutch Reformed Church in Venda, Rev. Faure Louw, who was stationed at the Tshilidzili Hospital of the Dutch Reformed Church in Africa. ${ }^{60}$

Dr H. Ramantswana contends that the Reformed Church of the Zoutpansberg Synod was not involved in the struggle against Venda's independence. Instead, the Reformed Church in its synod meetings prayed for the success of the Venda Legislative Assembly ${ }^{61}$ Rev. Mandiwana, a pastor of Meadowlands Reformed Church, was part of the Reformed Church in South Africa (1979-1980) Synod Midlands - one of the black synods of the Reformed Churches in South Africa served as consulate General for the Republic of Venda in South Africa. ${ }^{62}$ Unlike the foreign envoys from other countries who were stationed in Pretoria's white suburbs, Rev. Mandiwana was stationed in the black township of Soweto. The black ministers of the Reformed Church were not as vocal as their Lutheran counterparts. This was partly because their church had a firm grip on them and partly because their theological training had not exposed them to the socio-political dimension of the principles of justice and equality of all believers. ${ }^{63}$ Furthermore, ministers from the Dutch Reformed Church were heavily subsidised by the white churches. Any dissent would mean losing their stipend.

\section{BLACK CONSCIOUSNESS PHILOSOPHY EXPANDS UNDERSTANDING OF GOSPEL IMPERATIVES}

Factors such as the formation of the Venda Students' Association, the role of the church, the political consciousness of Christian students around 1976-1977, Venda's independence in 1979, and Frelimo's political victory in Mozambique played a major role in the intensification of resistance against the Venda government. ${ }^{64}$ According

59 This Act made provision for the establishment of separate tertiary institutions for "blacks", "Indians", "coloureds" and "whites". Blacks were not allowed to attend white universities, except with special permission from the government. The separation of these institutions was along both racial and ethnic lines. The University of Fort Hare was open to isiXhosa-speaking students only, while the University of the North in Turfloop was set up for the Sotho and Tswana students. Coloureds had their own university in Bellville, while Indians and Zulus had their universities in Durban-Westville and Ngoye (KZN), respectively. The establishment of this Act was met with protest from most lecturers at Fort Hare.

60 Louw was ordered to leave Venda within 10 hours of having his work permit withdrawn due to his involvement at the funeral of political detainee Tshifhiwa Isaac Muofhe in November 1981. He was not detained, because he was a white South African; whites were not subject to Homeland rules (Thovhogi: Interview, 13 December 2013).

61 Ramantswana: Interview, 3 December 2013.

6263

63 Ibid.

64 Truth and Reconciliation Commission (TRC) of South Africa: Report, Cape Town 1998, 374 381. 
to Mufamadi, the Student Association's aim was to promote the struggle against apartheid. The Venda government suspected that those principals and ministers who worked closely with the students were the main instigators of resistance. As a result, principals such as Lawrence Krorombi and Justice Thovhogi were detained for six months under suspicion of incitement. ${ }^{65,66}$

Most Lutheran ministers who openly resisted Venda's independence were former members of student organisations such as the Black People's Convention (BPC) and the South African Student Organisation (SASO), founded in 1968. They became aware of the evil of apartheid in their formative stages, in the early 1970s, during the Christian revival wave in the northern part of what is now the Limpopo Province. The revival gave rise to the Student Christian Movement (SCM) in high schools, ${ }^{67}$ the University Christian Movement (UCM) ${ }^{68}$ the Bold Evangelical Christian Organisation (BECO), the Zoutspansberg Independent Ministers Association (ZIMA), and the Pro-Frelimo Rallies ${ }^{69}$ as well as many other churchrelated revivals.$^{70}$ It was not difficult for the aspirant church leaders from the North to join the ranks of SASO upon arriving at the Umphumulo Lutheran Seminary near Pietermaritzburg in Natal. ${ }^{71}$

The Lutheran doctrine of the two kingdoms contributed to students' understanding of a holistic approach to salvation. They understood that the task of the Church was to serve God in Jesus Christ by the Spirit and for the sake of all. ${ }^{72}$ By the same token, the government is the servant of God and as such should implement just rules. According to Farisani, they understood diakonia as not merely aiming to ameliorate the consequences of social problems, but also calling attention to the causes of social injustice and structural poverty. ${ }^{73}$ The diaconate of all is an indispensable part of holistic ministry and mission with the whole people of God. ${ }^{74}$

65 Thovhogi: Interview, 13 December 2013.

66 Mufamadi, in TRC Report, 374-381.

67 Thovhogi: Interview, 13 December 2013.

68 Founded by Archbishop Robert Selby Taylor of the Anglican Church (Black Consciousness Movement, 1966, unpublished paper).

69 Frelimo rallies were held in recognition of the liberation of Mozambique from Portugal in 1974; Farisani: Interview, 9 December 2013.

70 Thovhogi: Interview, 13 December 2013.

71 Farisani and Steve Biko (founder of the Black Consciousness Movement) became soul mates on their first encounter and worked together closely until Biko's death in police detention in September 1977 (Farisani: Interview, 9 December 2013). Phaswana was elected President of SASO at Mpumulo Seminary (Phaswana: Interview, 16 November 2013). Rev. A.N. Mahamba, Rev. P.M. Phosiwa and T.I. Muofhe attended the same Lutheran Seminary in Natal in the late 1970s (Cape Times: 22 January 1982).

72 Paul Chung, Ulrich Duchrow and Craig L. Nessan: Liberating Lutheran Theology, Geneva 1989.

73 Farisani: Interview, 9 December 2013.

74 Ibid. 
Nearly all ministers who opposed the Venda government were, at some point, either members of the student organisations affiliated to the SASO or came under the direct influence of the Black Consciousness Movement. Some of them were expelled or suspended from the seminary but were later re-admitted to the ELCSA, first as evangelists and later as ministers. ${ }^{75}$ Their political activism from their school days onwards did not go unnoticed by the South African Security Police. They were detained, interrogated and tortured by people who had heard of them or knew details of their history. ${ }^{76}$ Most of them were kept under surveillance by the security police, who noted where they went in Venda, what they preached, and with whom they associated. ${ }^{77}$ Those who went to Venda after completing their studies at the seminary found themselves in direct conflict with the security apparatus of the Venda government.

The Black Consciousness Movement's origins were deeply rooted in Christianity, as was the case with other liberation movements, such as the ANC. ${ }^{78}$ Farisani had said that it was the Black Consciousness Movement, together with Steve Biko, its founding father, along with Biko's death in detention in September 1977, that expanded Farisani's understanding of socio-political issues. ${ }^{79}$ Farisani was later elected president of the Black People's Convention (BPC) of South Africa. It was from platforms such as these that he gained notoriety with the South African Security Police. The Black Consciousness Movement attacked traditional white values and the white monopoly on truth with a slogan: "Hi black man, you are on your own." This rallying cry led to the mushrooming of myriad forms of activism, culminating in the confrontation on 16 June 1976 in the Soweto uprising, when some 200 unarmed young people were killed. ${ }^{80}$

75 Ibid. Farisani was told of his suspension by the rector of the seminary, Dr Bekker, in 1972. He was accepted back into his church because of the role played by Dean Masekela. After studying through UNISA, Farisani was ordained in 1975, first as an evangelist and later as full minister, because of the results of his parish.

76 Detained in Venda in March 1977 for his prophetic preaching, Farisani was taken to Pietermaritzburg and Howick for interrogation. He believed this was done because "that was the nature of the torture"; perhaps his interrogators thought that because he had been schooled in Pietermaritzburg, his police detention in the city would have a psychological effect (Farisani: Interview, 9 December 2013).

77 Whenever anything happened, a crackdown on the ministers would immediately follow. Events such as the funeral of T.I. Muofhe, Farisani's sermon at the pre-independence rally on 9 September1979, Phaswana's visits and deliveries of food to political detainees, Phosiwa's preaching at Muofhe's funeral, and Faure Louw's care and comforting of Lillian, Muofhe's widow, all led to their immediate arrest or deportation.

78 The ANC was built on Christian principles as espoused by the founding fathers, who were clergy. This was also the case with the Black Consciousness Movement, which was formed by the Student Christian Movements. Biko: I Write What I Like, 2004.

79 Farisani: Interview, 9 December 2013.

80 Black Consciousness Movement: Black Consciousness, n.d., unpublished paper. 
The Black Consciousness Movement added a valuable dimension to the understanding of total liberation in South Africa. ${ }^{81}$ Authentic structural political changes first required a psychological transformation in the minds of black people themselves. ${ }^{82}$ Students attending traditionally black institutions were taught this philosophy and participated in black community projects and initiatives. By the time the government tried to act against the organisation, the basic tenets of the Black Consciousness Movement's philosophy of resistance and a culture of fearlessness had already spread, particularly among students. ${ }^{83}$ The Black Consciousness Movement stood in direct opposition to the tenets of the Republic of South Africa's Bantu Special Education Act of 1964, ${ }^{84}$ which provided for the control of non-white education, including teacher training. ${ }^{85}$

The Lutheran Seminary at Umphumulo had good lecturers (such as Bishop Manas Buthelezi) who taught a "total liberating gospel" and fully supported students who embraced the socio-political reality in South Africa as part of their liberating paradigm..$^{86}$ There were, however, also lecturers who did not encourage students to indulge in politics, such as the principal, Dr Becken. ${ }^{87}$ The diocesan council of the Northern Diocese stood by the students who were expelled from the seminary because of their political convictions. ${ }^{88}$

\section{THINGS GET WORSE FOR THE CLERICS}

The methods used in Venda's struggle against independence were copied and learnt from other situations in South Africa. The Soweto students' confrontation with the government, on 16 June 1976, frustrated the apartheid regime and its Homeland functionaries who advocated Homeland independence. The impact and magnitude of the confrontation in the Soweto uprising dealt a severe blow to a system that had no alternative plan. Brutality and detention with torture, in order to extract confessions from detainees opposing the system, became the only way of dealing with the situation. ${ }^{89}$ According to Farisani, the Venda student uprising was second

81 Farisani: Interview, 9 December 2013.

82 Black Consciousness Movement, n.d., unpublished paper.

83 Farisani: Interview, 9 December 2013.

84 Republic of South Africa, 1964.

85 Eiselen Commission on the Bantu Education Act, No. 24 of 1964, Pretoria.

86 Phaswana: Interview, 16 November 2013.

87 Dr Becken campaigned for the expulsion of students who engaged in politics. He and others opposed student political activism. This indicates that lecturers were divided on the political situation (Farisani: Interview, 9 December 2013).

88 Farisani: Interview, 9 December 2013.

89 Farisani: Interview, 9 December 2013; Phaswana: Interview, 16 November 2013. They cite many reasons for independence being forced on the people: white greed, Venda officials' love of material benefits, and love of power. 
in magnitude only to that in Soweto..$^{90}$ The Soweto student uprising gave impetus to Venda's struggle, as did its predecessors such as the rural revolts in the Transkei, Sekhukhuneland, the Marico and Witsieshoek in the 1960s. ${ }^{91}$

The young Lutheran ministers ordained in the mid-1970s and stationed in Venda territory faced a formidable task of truth-telling to those in power. Farisani, who often found himself at odds with the Security Police and his church, was a pioneer in the struggle against Venda's independence..$^{92}$ In one of his interrogations, a young policeman asked where he got his "communist ideas" from. The policeman suggested that Farisani was getting ideas of "communism" 93 from the Lutheran Seminary in $\mathrm{Nata}^{94}$ and that the lecturers who taught the students communism were from East Germany. ${ }^{95}$ It was accepted as a fact that those who opposed the policy of apartheid were communists and had to be exterminated. ${ }^{96}$ Russia, China, and Eastern Europe were viewed as the countries that propagated communist ideology. ${ }^{97}$

Farisani was taken to Pietermaritzburg after his first arrest. He was severely tortured and at the same time was offered the incentive of becoming a general bishop in the event of Venda's independence..$^{98}$ In one conversation with a South African colonel during his first detention in transit to Pietermaritzburg, he said:

But, Colonel, how can one see light in apartheid, equality in discrimination, love in hatred, trust in suspicion, life in death, and God in the devil? How can one see proper things in an improper system? Colonel, I am afraid I cannot agree with you; at least I have to be honest with myself. ${ }^{99}$

Both the South African and Venda authorities realised that Farisani was a gifted person, and hoped he could be bought over by the idea of becoming general bishop ${ }^{100}$ for Venda after independence. With this in mind, they invited him to preach at a Venda pre-independence rally on 9 September 1979, four days before Venda's independence on 13 September 1979. The Venda stadium was packed to capacity on

90 Farisani: Interview, 9 December 2013.

91 Mbeki: Peasants', n.p., 1964.

92 He was first arrested in March 1977, and was detained until June 1977. He was detained again from October 1977 to January 1978, and from October 1981 to January 1982.

93 Any ideas opposed to apartheid ideology that could consistently expose its folly were seen as black people accepting their own blackness and fighting whites' condescending attitudes (Farisani: Diary from a South African Prison, Philadelphia PA 1987, 28).

94 Farisani: Diary, 79.

95 Ibid.

96 Ibid.

97 Spence, J.E.: “Southern Africa in the Cold War," History Today 49, no. 2 (1999): 10.

98 Farisani: Interview, 9 December 2013.

99 Farisani: Diary, 28.

100 In his interrogation by a South African Colonel on the way to Pietermaritzburg, Farisani was told he was an intelligent young man who would be made a very important person if he could only see things properly (Farisani: Diary, 27). 
the day. ${ }^{101}$ After consulting with the diocesan council, he agreed to preach, provided that he could choose his own text and his sermon would not be censored. ${ }^{102} \mathrm{He}$ based his sermon on the parable of a foolish man who built his house on sand and the wise man who built on rock. He warned the Venda people not to ride on a horse that galloped without truth. ${ }^{103}$

The authorities were extremely annoyed by the sermon. That same night, Farisani's house was raided, and the police stayed there from 03:00 a.m. until 11:15 a.m. the next day. He was removed from the rest of the programme and banned from preaching at any official programme, although he had been scheduled to preach on Independence Day. ${ }^{104}$ Many attempts were made to entrap and even kill him. He was eventually arrested on 10 October $1979 .{ }^{105}$ The main reason for the arrest was probably his sermon at the pre-independence rally. The authorities' inclusion of Farisani in the pre-independence rally was a serious mistake that they would not repeat.

The public addresses and sermons by the Lutheran ministers went on unabated in Venda, but the situation worsened after the bombing of the Sibasa police station in the capital of Venda on 26 and 27 October 1981. Two policemen were killed, and a third was seriously injured. The immediate suspects included four Lutheran Church ministers and elders. A lay preacher, Tshifhiwa Isaac Muofhe, who planned to return to Umphumulo the following year to complete his studies, was taken into custody by the police for questioning. According to both Farisani and Phaswana, Muofhe ${ }^{106}$ had become a prime suspect because of the nature of his work. He was travelling in and out of the country selling products to clients in neighbouring countries, preparing himself to get back to the seminary the following day. He was suspected by the police of having provided transport to the people who bombed the police station. In the confusion and embarrassment, coupled with pressure from the South African police on Venda security, the Venda police became desperate. ${ }^{107}$ According to Wilmar Utting ${ }^{108}$ of The Star, the South African police "sneered" at the Venda police and told them to do something, question people, and track down the attackers.

The scorn of their counterparts from South Africa made the Venda police want to show how powerful they were; thus, they chose to make examples of people they did not approve of. Muofhe was one of them. According to the Sunday Express, he died of internal injuries in police custody in 1983 after he was severely beaten. ${ }^{109}$ Very little

101 Farisani: Interview, 9 December 2013.

102 Farisani: Diary, 61-63.

103 Ibid., 63.

104 Ibid., 63.

105 Farisani: Interview, 9 December 2013.

106 Interviews with Farisani (9 December 2013); and Phaswana (16 November 2013).

107 Sunday Times: 11 November 1981.

108 Ibid.

109 Sunday Express: 10 January 1982. 
is known about the circumstances that led to his death; according to Phaswana, the Venda government protected those who were responsible. Phosiwa, who preached at Muofhe's funeral, was arrested; Louw, who assisted Muofhe's widow, was deported; and Phaswana, who assisted with arrangements for Muofhe's post-mortem, was also arrested. Others were watched closely by the security police. ${ }^{110}$ At least 22 people were detained between the date of the Sibasa police station bombing on 28 October 1981 and 18 January 1982. ${ }^{111}$ The Venda Homeland was seized by fear and panic, with the people expecting follow-up attacks on key installations. The reaction of the Venda Security Police was brutal. Having failed to apprehend the cadres responsible for the attack, the police concluded that there were activists within the Homeland who were guilty of aiding and abetting the cadres, according the report published on 18 January 1982 in Fotw.net. ${ }^{112}$

Phaswana was one of the people detained almost immediately, one day after the bomb blast at the Sibasa police station. He had annoyed the Security Police by making food parcels and distributing them to political detainees, and his uncompromising, truth-telling sermons had got him into additional trouble. ${ }^{113} \mathrm{He}$ was again detained on 5 January 1982 and was accused of bombing the Sibasa police station. Detainees were routinely given paper to write a confession during the interrogation. Bishop Phaswana was also given a paper to write his confession, but instead he composed a sermon based on Luke 4, stating that God hated discrimination and oppression of the poor and widows. The sermon angered the police, and Phaswana was severely tortured, to the point where he lost consciousness. ${ }^{114}$

\section{RESPONSES OF CHURCH LEADERS}

The leadership of the Lutheran Church in the Devhula/Lebowa circuit ${ }^{115}$ supported its ministers throughout their ordeal. Bishop Serote was very active in mobilising the church and the outside world to become aware of the atrocities committed against apartheid protesters in Venda. Letters were written to the South African Council of Churches, the World Lutheran Federation and the World Council of Churches, asking them to pray for Christians in Venda. ${ }^{116}$ The Lutheran leadership organised legal teams for the detainees. Farisani has mentioned that Prof. K. Nürnberger, Dean P.M. Masekela, Dean M.C. Mminele, Bishop Martin Kruse, and Rev. Meissner visited him in prison. ${ }^{117}$ Rev. Mervyn Assur, general secretary of the Lutheran

110 Cape Times: 11 January 1982; Phaswana: Interview, 16 November 2013.

111 Cape Times: 18 January 1982.

112 http://www.fotw.net 07/01/1982.

113 Phaswana: Lutheran Forum, 47.

114 Phaswana: Interview, 16 November 2013.

115 The Northern Diocese covers the Venda territory (Phaswana: Lutheran Forum, 42-48).

116 Phaswana: Interview, 16 November 2013.

117 Farisani: Diary, 84. 
Church, mentioned that other ministers visited Farisani in Venda hospital as well. ${ }^{118}$ The Lutheran Church's general secretary in South Africa, who at that time was Rev. Reinholdt Schultz, sent a telegram to the Venda government protesting the detention of four Lutheran ministers. ${ }^{119}$

Previously, at its $11^{\text {th }}$ Church Council, the Lutheran Church had discussed the issues of Homeland independence and the unity of the church, the forced removals of people from their place of birth, the exclusion of black people in the proposed political dispensation, the influx control, the fate of African children under Bantu Education, the harassment of church workers by the security police, and the difficulty of obtaining travel documents for ministers. ${ }^{120}$ The $11^{\text {th }}$ Church Council resolved to send its five bishops to have a meeting with the prime minister of South Africa on all issues concerning segregation and discrimination against black people in South Africa.

On 1 February 1982, under the leadership of its general secretary, Bishop Desmond Tutu, and its president, Bishop Peter Storey, the delegation from the South African Council of Churches went to Venda to express "solidarity with fellow Christians who were being persecuted". ${ }^{121}$ Upon their arrival, they were refused permission to visit detainees and escorted back to the South African border by Venda National Defence Force vehicles. ${ }^{122}$ Tutu described the Venda police at roadblocks to Thohoyandou as so ruthless that he would rather be arrested in South Africa if given the choice. ${ }^{123}$

The news of the torture of Lutheran ministers in Venda spread throughout the world. Deputy Bishop Uwe Hollm from Berlin visited Farisani in a Venda prison as well. ${ }^{124}$ The visit by the team from the International Red Cross and the campaign by the Lutheran World Federation, augmented by Amnesty International ${ }^{125}$ and local churches, brought pressure to bear on the Venda government. Eventually the detained ministers, Farisani, Mahamba, Phaswana and Phosiwa were charged. The charges against Phaswana were withdrawn. Phosiwa was convicted on the lesser charge of having helped cadres bomb the police station and given a suspended sentence. ${ }^{126}$ Pressure and outcry from churches and civil society from South Africa were extended to the governments of the United States of America, West Germany and Great Britain to the extent that the Reagan administration and the German government expressed their concern about the people who had died and those who

118 Daily Dispatch: 16 January 1982; Rand Daily Mail: 16 January 1982.

119 Daily Dispatch: 8 January 1982.

120 Minutes of 11th Church Council, held in Braamfontein on 24-27 October 1977.

121 Rand Daily Mail: 2 February 1982.

122 Ibid.

123 Sowetan: 2 February 1982.

124 Farisani: Diary, 82.

125 The Star: 27 January 1982.

126 Farisani: Diary, 89. 
were in detention in Venda prisons because of their political convictions. They communicated these concerns to the South African government. These international communities did not recognise the Homeland system. ${ }^{127}$ Hence, as a result of the economic ties between these Western countries and South Africa and the pressure they could bring to bear on the country, the South African government was persuaded to release the detainees. The Lutheran World Federation, as well as the World Council of Churches, held emergency meetings in Geneva and communicated their concerns to the South African government. ${ }^{128}$ The detained ministers were eventually released - not because the authorities changed their minds, but because of an attempt on the part of Pretoria to control the damage after the exposure of these atrocities. ${ }^{129}$

\section{CONCLUSION}

The article tried to show how church clergy resisted the Venda independence under very difficult conditions. The Venda government acted ruthlessly against them, but they would not relent. Some of them carry permanent scars on their bodies that serve as a testimony of what they stood for. The Venda episode is a testimony showing what the church of Jesus Christ can do through its witness - fearing not those who can kill the body but rather the "One who kills the body and soul in hell" (Matt.10:28).

This article attempted to trace the spirit and influence of the Black Consciousness Movement and its impact on the ELCSA. The theology of ministers such a Farisani, Phaswana, Ramashapha and many others, was deeply influenced by the Black Consciousness Movement, which was profoundly theological and dealt with the issues that affected people. Their theology was tailored to liberate black people who had accepted the lie of apartheid and who went along with the South African government's false inventions of Venda's independence.

\section{REFERENCES}

Biko, S. I Write What I Like. London, 2004.

Black Consciousness Movement: The Black Consciousness Movement. n.d. (Unpublished).

Black Consciousness: The Black Consciousness Movement. 1966. (Unpublished).

Cape Times: 10 February 1982.

Cape Times: 11 January 1981.

Cape Times: 18 January 1982.

Cape Times: 22 January 1982.

Chung, Paul, Ulrich Duchrow and Craig, L. Nessan. Liberating Lutheran Theology. Geneva, 1989.

127 Cape Times: 22 January 1982.

128 Farisani: Diary, 89.

129 Ibid. 
Claassens, Aninka. "The Myth of Voluntary Removals," in The Black Sash, May 1994, 20-30. http://www.historicalpapers.wits.ac.za/inventories/inv_pdfo/AK2117/AK2117 -J7-DA151002-jpeg.pdf (accessed 26 December 2013).

Crafford, D. Trail-blazers of the Gospel, Black Pioneers in the Missionary History of Southern Africa. Pro Christo. Bloemfontein 1991.

Crafford, D. Aan God die Dank. Pretoria, 1982.

Daily Dispatch: 8 January 1982.

Daily Dispatch: 16 January 1982.

Eiselen Commission on the Bantu Education Act, No 24 of 1964. Pretoria. sahistory.org.za/pages/ governance-projects (accessed 23 October 2013).

Farisani, T.S. Dean: Evangelical Lutheran Church in Southern Africa. Interview: 9 December 2013.

Farisani, T.S. Diary from a South African Prison. Philadelphia, PA, 1987.

Geldenhuys, D. South Africa's Black Homelands. Past Objectives, Present Realities and Future Developments. The South African Institute of International Affairs. Braamfontain, 1981.

Kgatla, S. Thias. Polokwane Congregation. Uniting Reformed Church in Southern Africa: An Historical Survey since 1890. Church Booklet published for Church Inauguration. Polokwane, 2013.

Kgatla, S. Thias. The Dutch Reformed Church Mission since 1863-1964. Unpublished M.Th. dissertation submitted to the University of South Africa, 1988.

Kirkaldy, Alan. Capturing the Soul. The Vhavenda and Missionaries. Pretoria, 2005.

Mbeki, Govan. The Peasants Revolt. Johannesburg, 1964.

Minutes of $11^{\text {th }}$ Church Council held in Braamfontein on 24-27 October 1977.

Minutes of Methodist Conference, 1977.

Mufamadi. TRC Report, 374-381, 1999.

Phaswana, N.P. "Global Lutheranism: A Lutheran Bishop's Apartheid Memoirs." Lutheran Forum 47 no. 3 (2013): 42-48.

Phaswana, N.P. Bishop: Evangelical Lutheran Church in Southern Africa, Central Diocese. Interview, 16 November 2013.

Ramantswana, H. Senior Lecturer at University of South Africa: Interview, 3 December 2013.

Rand Daily Mail: 5 January 1982.

Rand Daily Mail: 16 January 1982.

Rand Daily Mail: 19 January 1982.

Rand Daily Mail: 2 February 1982.

Seakamela, Uriah. Dean: Interview, 28 November 2013.

Smith, N.J. Elkeen in sy Eie Taal. N.G. Kerk Boekhandel. Pretoria, 1972.

South Africa, Union of: Native Affairs Act, No 23 of 1920. Pretoria, 1920.

South Africa, Union of: Bantu Authorities Act, No 68 of 1951. Pretoria, 1951.

South Africa, Republic of: Bantu Special Education Act, No 24 of 1964. Pretoria, 1964.

South Africa, Republic of: Proclamation R. 168 of 20 June 1969. Pretoria, 1969. 
South Africa, Republic of: Bantu Homelands Citizenship Act, No 26 of 1970/National States Citizenship Act, No 26 of 1970. Pretoria, 1970.

South Africa, Republic of: Black States Constitution Act, No 21 of 1971. (Also called the Bantu Homelands/Black Homelands/Self-Governing Territories Constitution Act). Pretoria, 1971.

Sowetan, 4 January 1982.

Sowetan, 2 February 1982.

Spence, J.E. "Southern Africa in the Cold War." History Today 49, no. 2 (1999).

Sunday Express: 10 January 1982.

Sunday Express: 17 January 1982.

Sunday Express: 10 October 1982.

Sunday Times: 11 November 1981.

The Star: 27 January 1982.

Thovhogi, Justice: Interview, 13 December 2013.

Truth and Reconciliation Commission (TRC) of South Africa: Report. Cape Town, 374-381, 1998.

Turok, B. Readings in the ANC Tradition. Volume 1 Policy and Praxis. Cape Town, 2011.

Uhuru: n.d. Unpublished. 